Vol. 6, No. 1, Februari 2018

Efektifitas Media Film dengan Leaflet dalam Peningkatan Pengetahuan Ibu Rumah Tangga tentang DBD di Desa Pekalongan Kabupaten Pati

Dobby Raka Sandi Susetya, Ervi Rachma Dewi

Menggali Kefektifan Peran Ibu dengan Anak Usia Pra Sekolah selama Berada di Rutan Kudus Aliani Nailil Izzah, Sri Hindriyastuti

Perbedaan Kadar BOD Limbah Cair Sebelum dan Setelah melewati Biofilter Tanaman Cattail (Typha angustifolia) Pujo Prasetyo, David Laksamana Caesar

Gambaran Kepatuhan Ibu dalam Pelaksanaan Imunisasi DPT/Hb Lengkap di Puskesmas Punggelan 2 Kabupaten Banjarnegara Lia Aria Ratmawati, Rosiyani Hermawati

Hubungan Riwayat Kontak Penderita dengan Kejadian Tuberkulosis Paru Anak Usia 1-14 Tahun di Balai Kesehatan Masyarakat Pati Risna Endah Budiati, Noor Khoirina

Hubungan Dukungan Keluarga dengan Pemberian ASI Eksklusif pada Bayi di Desa Jambean Kidul Kecamatan Margorejo Nanik Royaningsih, Sri Wahyuningsih

Jumlah Kehamilan dan Kematian Ibu Berdasarkan Letak Wilayah Ketinggian di Kabupaten Pekalongan Rokhani, Indri Astuti Purwanti 


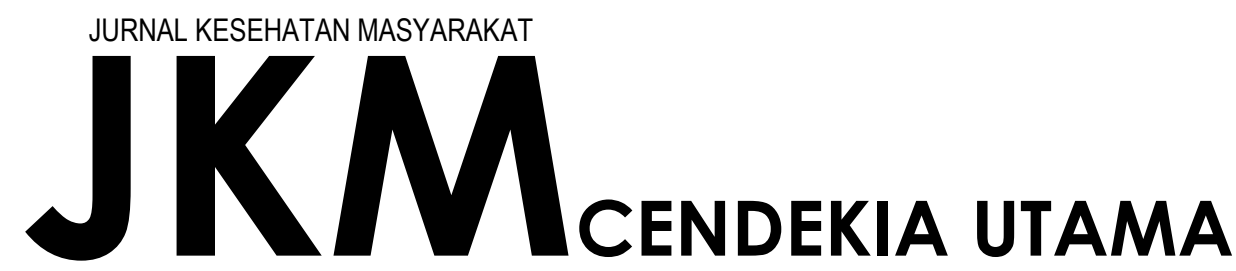


Vol. 6 No. 1

P-ISSN 2338-6347

Februari, 2018

E-ISSN 2580-992X

\section{$\mathbf{J} \mathbf{M}_{\text {cendekia utama }}$}

\section{Editor in Chief}

Eko Prasetyo, S.KM., M.Kes. STIKES Cendekia Utama Kudus, Indonesia

\section{Editorial Board}

Sri Wahyuningsih, S.KM., M.Gizi., STIKES Cendekia Utama Kudus, Indonesia Risna Endah Budiati, S.KM., M.Kes., (Epid), STIKES Cendekia Utama Kudus, Indonesia

Ervi Rachma Dewi, S.KM., M.Kes., STIKES Cendekia Utama Kudus, Indonesia David Laksamana Caesar, S.KM., M.Kes., STIKES Cendekia Utama Kudus, Indonesia

\section{Reviewer}

Sigit Ari Saputro, S.KM., M.Kes., Universitas Airlangga, Surabaya, Indonesia dr. Mahalul Azam, M.Kes., Universitas Negeri Semarang, Indonesia

Eti Rimawati, S.KM., M.Kes., Universitas Dian Nuswantoro, Semarang, Indonesia Didik Sumanto, S.KM., M.Kes. (Epid), Universitas Muhammadiyah Semarang, Indonesia

\section{English Language Editor}

Arina Hafadhotul Husna, M.Pd., STIKES Cendekia Utama Kudus, Indonesia

\section{IT Support}

Susilo Restu Wahyuno, S.Kom, STIKES Cendekia Utama Kudus, Indonesia

JKM (Jurnal Kesehatan Masyarakat) Cendekia Utama merupakan jurnal ilmiah dalam bidang kesehatan masyarakat yang diterbitkan oleh Program

Studi S1 IImu Kesehatan Masyarakat STIKES Cendekia Utama Kudus secara berkala dua kali dalam satu tahun 


\section{KATA PENGANTAR}

Salam MIRACLE,

Puji syukur selalu senantiasa kita panjatkan kehadirat Allah SWT yang telah melimpahkan Rahmah Hidayah dan Ilmu-Nya, sehingga JKM (Jurnal Kesehatan Masyarakat) Cendekia Utama Kudus Vol. 6, No. 1 dapat kembali terbit pada bulan Februari 2018 ini. Pada kesempatan yang baik ini kami menyampaikan ucapan terima kasih dan apresiasi yang setinggi-tingginya kepada bapak ibu mitra bestari, para peneliti, tim redaksi, dan semua pihak yang telah mendukung atas terbitnya JKM Cendekia Utama Vol. 6, No. 1 ini.

JKM Cendekia Utama merupakan jurnal ilmiah di bidang kesehatan masyarakat yang diterbitkan secara berkala 2 (dua) kali dalam setahun oleh Program Studi S1 Ilmu Kesehatan Masyarakat STIKES Cendekia Utama Kudus. JKM Cendekia Utama mempublikasikan informasi ilmiah hasil penelitian dengan kajian: Epidemiologi, Kesehatan Lingkungan, Keselamatan dan Kesehatan Kerja (K3), Promosi Kesehatan, Biostatistik dan Kependudukan, Administrasi Kebijakan Kesehatan (AKK), Manajemen Kesehatan, Gizi Masyarakat, Kesehatan Ibu dan Anak (KIA), Kesehatan Reproduksi, dan kajian-kajian pengembangan ilmu di bidang kesehatan masyarakat.

JKM Cendekia Utama kembali mengundang berbagai ilmuan dari berbagai lembaga pendidikan tinggi maupun peneliti untuk memberikan sumbangan ilmiahnya dalam bentuk artikel ilmiah dari hasil penelitian, laporan/studi kasus, kajian/tinjauan pustaka di bidang kesehatan masyarakat dalam rangka mengatasi permasalahan kesehatan masyarakat yang semakin kompleks.

Redaksi sangat mengharapkan masukan-masukan dari para pembaca dan professional bidang kesehatan masyarakat untuk peningkatan kualitas jurnal dan berharap semoga artikel-artikelyang termuat dalam JKM Cendekia Utama bermanfaat dalam pengembangan ilmu di bidang kesehatan masyarakat.

\section{Pimpinan Redaksi}

Eko Prasetyo, S.KM., M.Kes. 


\section{DAFTAR ISI}

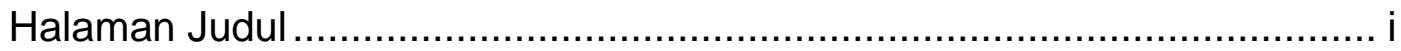

Susunan Dewan Redaksi..................................................................

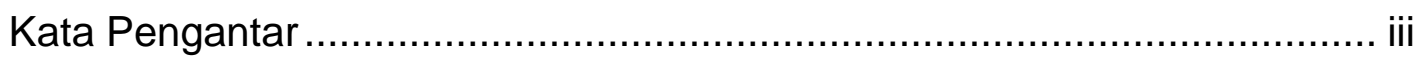

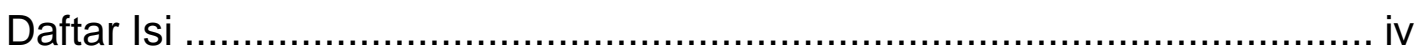

Efektifitas Media Film dengan Leaflet dalam Peningkatan Pengetahuan Ibu Rumah Tangga tentang DBD di Desa Pekalongan Kabupaten Pati Dobby Raka Sandi Susetya, Ervi Rachma Dewi........................................ 1

Menggali Kefektifan Peran Ibu dengan Anak Usia Pra Sekolah selama Berada di Rutan Kudus

Aliani Nailil Izzah, Sri Hindriyastuti........................................................ 16

Perbedaan Kadar BOD Limbah Cair Sebelum dan Setelah melewati Biofilter Tanaman Cattail (Typha angustifolia)

Pujo Prasetyo, David Laksamana Caesar

Gambaran Kepatuhan Ibu dalam Pelaksanaan Imunisasi DPT/Hb Lengkap di Puskesmas Punggelan 2 Kabupaten Banjarnegara

Hubungan Riwayat Kontak Penderita dengan Kejadian Tuberkulosis Paru Anak Usia 1-14 Tahun di Balai Kesehatan Masyarakat Pati Risna Endah Budiati, Noor Khoirina.

Hubungan Dukungan Keluarga dengan Pemberian ASI Eksklusif pada Bayi di Desa Jambean Kidul Kecamatan Margorejo

Jumlah Kehamilan dan Kematian Ibu Berdasarkan Letak Wilayah Ketinggian di Kabupaten Pekalongan

Rokhani, Indri Astuti Purwanti 62

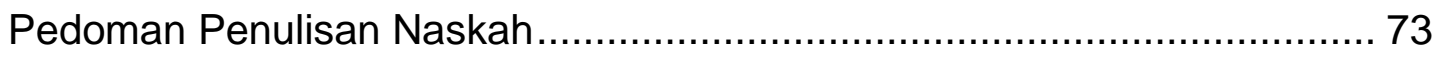

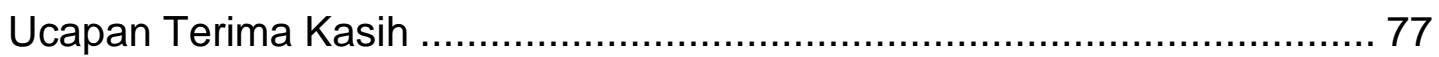




\title{
GAMBARAN KEPATUHAN IBU DALAM PELAKSANAAN IMUNISASI DPT/HB LENGKAP DI PUSKESMAS PUNGGELAN 2 KABUPATEN BANJARNEGARA
}

\author{
Lia Aria Ratmawati ${ }^{1}$ Rosiyani Hermawati ${ }^{2}$ \\ 1,2Program Studi DIII Kebidanan \\ Politeknik Banjarnegara \\ E-mail : liaaria13@gmail.com; rosiyani86@gmail.com
}

\begin{abstract}
ABSTRAK
Puskemas Punggelan 2 merupakan salah satu Puskesmas dengan cakupan imunisasi DPT1+HB1 dan DPT3+HB3 terendah di Kabupaten Banjarnegara. Tujuan penelitian ini adalah mengetahui gambaran kepatuhan ibu dalam pelaksanaan imunisasi DPT/HB lengkap berdasarkan keterjangkauan di Puskesmas Punggelan 2 Kabupaten Banjarnegara. Penelitian ini menggunakan pendekatan Cross Sectional dengan teknik cluster sampling. Analisis data distribusi frekuensi dan cross tabulasi. Hasil penelitian kepatuhan imunisasi DPT/HB lengkap di Puskesmas Punggelan 2 sebagian besar kategori tidak patuh sebanyak 45 responden (54.2\%) serta keterjangkauan mencapai layanan kesehatan masih tergolong sulit sebanyak 48 responden (57.8\%). Kepatuhan imunisasi DPT/HB lengkap berdasarkan keterjangkaun di Puskesmas Punggelan 2 sebanyak 33 (39.7\%) responden tidak patuh dalam pelaksanaan imunisasi dan sulit menjangkau layanan kesehatan. Saran penelitian diharapkan Puskesmas Punggelan 2 terutama pengelola program KIA lebih memperhatikan masyarakat yang memiliki bayi balita agar melakukan imunisasi sesuai interval dengan memperbanyak posyandu yang ada di desa sehingga lebih dekat dengan masyarakat agar cakupan imunisasi di Puskesmas Punggelan 2 dapat lebih baik lagi.
\end{abstract}

Kata kunci: kepatuhan, keterjangkauan, imunisasi

\begin{abstract}
Puskemas Punggelan 2 is one of health center with the lowest DPT1 $+\mathrm{HB1}$ and DPT3+HB3 immunization in Banjarnegara. The purpose of this research is to know the description of maternal obedience in the implementation of complete DPT / HB immunization based on affordability at Punggelan 2 Puskesmas Banjarnegara District. This research uses Cross Sectional approach with cluster sampling technique. Data analysis of frequency distribution and cross tabulation. The result of the complete immunization immunization of DPT / HB at Punggelan 2 Public Health Center mostly non compliance category as many as 45 respondents (54.2\%) and the affordability to reach health service is still difficult as many as 48 respondents (57.8\%). Complete DPT / HB immunization compliance based on affordability at Punggelan 2 Puskesmas as many as 33 (39.7\%) respondents did not comply with immunization and difficult to reach health services. Research suggestion Punggelan 2 Puskesmas expected especially
\end{abstract}


MOM program managers pay more attention to people who have babies to make immunization at intervals by increasing posyandu in the village so that closer to the community for immunization coverage in Punggelan 2 Puskesmas can be better.

Keywords: compliance, affordability, immunization 


\section{PENDAHULUAN}

Salah satu upaya pencegahan penyakit yaitu melalui pemberian imunisasi. Pemahaman imunisasi diperlukan sebagai dasar dalam memberikan asuhan keperawatan terutama pada anak sehat dan implikasi konsep imunisasi pada saat merawat anak sakit khususnya pada kasus tuberkulosis, difteri, pertusis, tetanus, polio, campak, dan hepatitis (PD3I) [1]. Imunisasi diupayakan untuk meningkatkan kekebalan pejamu terhadap penyakit tertentu sehingga dapat melawan mikroorganisme penyebab penyakit, tanpa harus mengalami sakit terlebih dahulu [2].

Jadwal pemberian imunisasi DPT adalah diberikan 3 kali sejak umur 2 bulan (tidak boleh diberikan sebelum umur 6 minggu) dengan interval 4-6 minggu. DPT-1 umur 2 bulan. DPT-2 umur 3 bulan. DPT-3 umur 4 bulan[3]. DPT 1 diberikan umur 2-4 bulan, DPT 2 umur 3-5 bulan, dan DPT 3 umur 4-6 bulan [4]. Untuk imunisasi yang harus diberikan beberapa kali dengan interval waktu tertentu agar kadar antibodi yang diinginkan tercapai (di atas ambang perlindungan), contohnya seperti vaksin DPT, polio. Hib, pneumoni konjugasi, hepatitis $A$ ata hepatitis $B$, keterlambatan atau memanjangnya interval tidak bermakna mempengaruhi respon imunologis dalam membentuk antibodi. Jumlah pemberian imunisasi tetap harus dilengkapi supaya kadar ambang perlindungan bisa dicapai dan anak terlindung dari penyakit. Keterlambatan akan menunda tercapainya ambang kadar antibodi yang memberikan perlindungan tersebut sehingga resiko tertular atau terkena penyakit yang ingin dicegah masih tetap tinggi [2].

Indikator keberhasilan pelaksanaan imunisasi diukur dengan pencapaian UCl (Universal Child Immunization) desa/ kelurahan, yaitu minimal $80 \%$ bayi di desa/ kelurahan telah mendapatkan imunisasi dasar lengkap. Data bahwa imunisasi terendah salah satunya terdapat di wilayah Puskesmas Punggelan 2, terutama imunisasi DPT1+HB1 $(84,5 \%)$ dan DPT3+HB3 $(77,9 \%)$ dari data tersebut dapat dikatakan bahwa cakupan imunisasi tidak sesuai dengan target Kabupaten 
Banjarnegara. Berdasarkan studi pendahuluan melalui wawancara dengan Bidan di Puskesmas Punggelan penyebab angka cakupan pada imunisasi DPT/HB rendah disebabkan karena ibu yang membawa anaknya untuk imunisasi DPT/ HB interval waktunya lebih dari 6 minggu serta masih sulitnya keadaan jalan dan masih adanya kepercayaan pada ibu tertentu untuk tidak melakukan imunisasi pada anaknya. Hasil observasi kepada ibu bayi bahwa mereka memberikan imunisasi pada anaknya dengan interval waktu melebihi interval 6 minggu dari imunisasi sebelumnya. Sehingga peneliti mengambil penelitian dengan judul Gambaran Kepatuhan Ibu dalam Pelaksanaan Imunisasi DPT/HB Lengkap Di Puskesmas Punggelan 2 Kabupaten Banjarnegara.

\section{METODE PENELITIAN}

Penelitian ini menggunakan jenis penelitian deskriptif. Penelitian deskriptif yaitu suatu metode penelitian diarahkan untuk mendeskripsikan atau menguraikan suatu keadaan di dalam suatu komunitas atau masyarakat [5] dengan menggunakan pendekatan Cross Sectional yaitu tiap subjek penelitian hanya diobservasi sekali saja dan pengukuran dilakukan terhadap status karakter atau variabel subjek pada saat pemeriksaan [5].

Populasi dalam penelitian ini adalah semua ibu yang memberikan imunisasi DPT/ HB lengkap sejumlah 487 bayi dengan teknik cluster sampling yaitu suatu cara pengambilan sampel bila objek yang diteliti atau sumber data sangat luas atau besar, yakni populasinya heterogen dan terdiri atas kelompok yang masing-masing heterogen [6]. Cluster dilakukan dengan cara melakukan rendomisasi untuk cluster/menentukan sampel daerah kemudian randomisasi/ menentukan orang cluster yang dipilih. Total sampel dari seluruh desa di Puskesmas Punggelan 2 yaitu 83 responden. Teknik pengumpulan data dalam penelitian ini menggunakan data primer melalui wawancara kepada responden (checklist) dengan dan data sekunder untuk mengetahui data kelengkapan imunisasi DPT/HB lengkap $(1,2,3)$ 
menggunakan kohort bayi dan buku KIA sedangkan untuk keterjangkauan pelayanan kesehatan dapat kilometer (meteran/ spidometer) dan menggunakan waktu (jam).

HASIL DAN PEMBAHASAN

a. Gambaran Kepatuhan Imunisasi DPT/HB lengkap di Puskesmas Punggelan 2

Tabel 1

Distribusi Frekuensi Kepatuhan Imunisasi DPT/HB lengkap di Puskesmas Punggelan 2

\begin{tabular}{llcc}
\hline No & $\begin{array}{c}\text { Kepatuhan Imunisasi Lengkap } \\
\text { DPT/HB lengkap }\end{array}$ & $\boldsymbol{f}$ & $\%$ \\
\hline 1 & Patuh & 38 & 45.8 \\
2 & Tidak Patuh & 45 & 54.2 \\
& Jumlah & 83 & 100 \\
\hline
\end{tabular}

Pada penelitian ini diketahui bahwa di Puskesmas Punggelan 2 dalam melaksanakan imunisasi DPT/HB lengkap masih banyak yang tidak patuh yaitu sebanyak $45(54.2 \%)$ responden sedangkan yang patuh yaitu 38 (45.8\%) responden. Ini menunjukan bahwa masih banyak masyarakat yang tidak patuh dalam pelaksanaan imunisasi yang sesuai dengan interval 4-6 minggu.

Imunisasi DPT dasar diberikan 3 kali sejak anak umur dua bulan dengan interval 4-6 minggu [4]. Keterlambatan akan menunda tercapainya ambang kadar antibodi yang memberikan perlindungan tersebut sehingga resiko tertular atau terkena penyakit yang ingin dicegah masih tetap tinggi [2].

Untuk imunisasi yang harus diberikan beberapa kali dengan interval waktu tertentu agar kadar antibodi yang diinginkan tercapai (di atas ambang perlindungan), contohnya seperti vaksin DPT, polio, Hib, pneumokok konjugasi, hepatitis $A$ atau hepatitis $B$, keterlambatan atau memanjangnya interval tidak bermakan mempengaruhi respon imunologis dalam membentuk antibodi. Jumlah pemberian imunisasi tetap harus dilengkapi supaya kadar ambang perlindungan bisa dicapai dan anak terlindung dari penyakit. Keterlambatan akan menunda tercapainya ambang kadar antibodi yang memberikan perlindungan 
tersebut sehingga resiko tertular atau terkena penyakit yang ingin dicegah masih tetap tinggi [2].

Frekuensi dan jarak pemberian juga mempengaruhi respon imun. Bila pemberian vaksin berikutnya diberikan pada saat kadar antibodi spesifik masih tinggi, maka antigen yang masuk akan segera dinetralkan, sehingga tidak sempat merangsang sel imunokompeten, bahkan dapat terjadi reaksi arthus, yaitu bengkak kemerahan di daerah suntikan antigen akibat pembentukan kompleks antigen antibody lokal. Pemberian vaksin ulang (booster) sebaiknya mengikuti anjuran sesuai hasil uji klinis [3].

\section{b. Gambaran Keterjangkauan Dalam Melaksanakan Imunisasi DPT/HB lengkap di Puskesmas Punggelan 2}

\section{Tabel 2}

Distribusi Frekuensi Keterjangkauan Dalam Melaksanakan Imunisasi DPT/HB lengkap di Puskesmas Punggelan 2

\begin{tabular}{clcc}
\hline No & \multicolumn{1}{c}{ Keterjangkauan } & $\boldsymbol{f}$ & $\%$ \\
\hline 1 & Mudah Dijangkau & 35 & 42.2 \\
2 & Sulit Dijangkau & 48 & 57.8 \\
& Jumlah & 83 & 100 \\
\hline
\end{tabular}

Berdasarkan hasil penelitian menunjukan bahwa keterjangkauan dalam melaksanakan imunisasi DPT/HB lengkap di Puskesmas Punggelan 2 dalam menjangkau pelayanan masih tergolong sulit yaitu sebanyak 48 (57.8\%) responden dan yang mudah untuk menjangkau pelayanan kesehatan hanya $35(42.2 \%)$ responden.

Keterjangkauan atau akses, artinya layanan kesehatan itu harus dapat dicapai oleh masyarakat, tidak terhalang oleh keadaan geografis, sosial, ekonomi, organisasi dan bahasa. Akses geografis diukur dengan jarak, lama perjalanan, biaya perjalanan, jenis transportasi, dan/atau hambatan fisik lainnya yang dapat menghalangi seseorang untuk mendapat layanan kesehatan [7].

Kementrian kesehatan memberikan definisi umum bahwa suatu daerah terpencil/sangat terpencil adalah wilayah yang sulit/sangat sulit 
dicapai karena beberapa penyebab seperti kondisi geografis (pulau, bergunung-gunung, tanah, hutan, dan rawa), alat transportasi, dan sosial budaya [8].

c. Gambaran kepatuhan ibu dalam pelaksanaan imunisasi DPT/HB lengkap berdasarkan keterjangkauan di Puskesmas Punggelan 2

Tabel 3

Gambaran Kepatuhan Ibu Dalam Pelaksanaan Imunisasi DPT/HB Lengkap Berdasarkan Keterjangkauan Di Puskesmas Punggelan 2

\begin{tabular}{lccccccc}
\hline $\begin{array}{l}\text { Kepatuhan } \\
\text { Imunisasi } \\
\text { DPT/HB }\end{array}$ & \multicolumn{4}{c}{ Jarak Tempuh Rumah Ke Puskesmas } & & \multicolumn{2}{c}{ Total } \\
\cline { 2 - 5 } \begin{tabular}{l} 
lengkap \\
\cline { 2 - 5 }
\end{tabular} & $\boldsymbol{F}$ & $\%$ & $\boldsymbol{f}$ & $\%$ & $\boldsymbol{f}$ & \\
\hline Patuh & 23 & 27.7 & 15 & 18.0 & 38 & 45.7 \\
Tidak Patuh & 12 & 14.6 & 33 & 39.7 & 45 & 54.3 \\
Total & 35 & 42.3 & 48 & 57.7 & 83 & 100 \\
\hline
\end{tabular}

Tabel diatas menunjukan bahwa gambaran kepatuhan ibu dalam pelaksanaan imunisasi DPT/HB lengkap berdasarkan keterjangkauan di Puskesmas Punggelan 2 yang menyatakan patuh dalam pelaksanaan imunisasi DPT/HB lengkap dengan jarak tempuh rumah kepelayanan kesehatan mudah dijangkau yaitu sebanyak 35 (42.3\%) responden dan sulit dijangkau $48(57.7 \%)$ responden, sedangkan yang tidak patuh imunisasi DPT/HB lengkap dengan jarak tempuh rumah kepelayanan kesehatan mudah dijangkau 12 (14.6\%) responden, dan yang sulit dijangkau yaitu sebanyak $33(39.7 \%)$ responden.

Hal ini didukung oleh teori Pohan yang mengatakan bahwa keterjangkauan atau akses, artinya layanan kesehatan itu haru dapat dicapai oleh masyarakat, tidak terhalang oleh keadaan geografis sosial, ekonomi, organisasi dan bahasa. Akses geografis diukur denga jarak, lama perjalanan, biaya perjalanan, jenis transportasi, dan/atau hambatan fisik lainnya yang dapat menghalangi seseorang untuk mendapat layanan kesehatan [7].

Kepatuhan menuntut adanya perubahan perilaku, yang dipengaruhi secara positif oleh meliputi, rasa percaya yang terbentuk sejak awal dan berkelanjutan terhadap tenaga kesehatan profesional, penguatan dari 
orang terdekat, persepsi tentang kerentanan diri terhadap penyakit, persepsi bahwa penyakit yang diderita serius, bukti bahwa kepatuhan mampu mengontrol munculnya gejala atau penyakit, efek samping yang bisa ditoleransi, tidak terlalu mengganggu aktivitas seharian individu atau orang terdekat lainnya, terapi lebih banyak memberikan keuntungan dari pada kerugian, rasa positif terhadap diri sendiri [9].

Sedangkan untuk yang patuh imunisasi DPT/HB lengkap namun sulit dijangkau pelayanan kesehatan sebanyak $23(27.7 \%)$ responden. Hal ini didukung oleh teori bahwa kepatuhan bergantung pada banyak faktor, termasuk motivasi individu, persepsi tentang kerentanan, dan keyakinan terhadap upaya pengontrolan dan pencegahan penyakit, variabel lingkungan, kualitas instruksi kesehatan, dan kemampuan mengakses sumber yang ada (biaya, keterjangkauan) [9]. Sedangkan untuk yang tidak patuh imunisasi DPT/HB lengkap dengan jarak tempuh rumah kepelayanan kesehatan mudah dijangkau 12 (14.6\%) responden, dan yang sulit dijangkau yaitu sebanyak 33 (39.7\%) responden. Kepatuhan dihambat oleh penjelasan yang tidak adekuat, perbedaan pendapat antara klien dan tenaga kesehatan, terapi jangka panjang, tingginya kompleksitas atau biaya pengobatan, tingginya jumlah dan tingkat keparahan efek samping [9].

Hasil penelitian menyatakan bahwa sebenyak 33(73,3\%) responden tidak patuh dalam pelaksanaan imunisasi DPT/HB lengkap hal tersebut dikarenakan oleh layanan kesehatan yang sulit untuk dijangkau oleh responden. Berikut ini merupakan penjabaran yang patuh imunisasi DPT/HB, untuk yang 5 minggu pada DPT/HB 1-2 berjumlah $28(37,3 \%)$ responden, DPT/HB 2-3 ada 12 (16\%) responden dan DPT/HB 1-2-3 sebanyak $35(46,6)$ responden. Untuk yang patuh dalam interval 6 minggu ada $3(100 \%)$ responden. Sedangkan untuk yang tidak patuh pada DPT/HB 1-2 ada 9 (20\%) responden, DPT/HB 2-3 ada $28(62,2 \%)$ responden, dan untuk DPT/HB 1-2-3 ada 8 (17,7\%) responden. Suatu daerah yang sulit dijangkau sangat mempengaruhi kepatuhan 
pelaksanaan imunisasi DPT/HB hal itu menyebabkan cakupan imunisasi yang ada di Puskesmas Punggelan 2 rendah.

Hal ini sesuai dengan teori yang menyampaikan bahwa keterjangkauan masyarakat terhadap layanan kesehatan dan keterjangkauan petugas kesehatan dalam memberikan layanan kepada masyarakat, terutama petugas puskesmas. Jika letak tempat pelayanan kesehatan jauh dari pemukiman penduduk, kemungkinan masyarakat akan sulit menjangkaunya [10].

\section{SIMPULAN DAN SARAN}

\section{Simpulan}

1. Kepatuhan imunisasi DPT/HB lengkap yang ada di Puskesmas Punggelan 2 sebagian besar dalam kategori tidak patuh sebanyak 45 responden (54.2\%).

2. Keterjangkauan dalam mencapai layanan kesehatan di Puskesmas Punggelan 2 masih tergolong sulit sebanyak 48 responden (57.8\%).

3. Kepatuhan imunisasi DPT/HB lengkap berdasarkan keterjangkauan di Puskesmas Punggelan 2 sebanyak 33 (39.7\%) responden sebagian besar masih tidak patuh dan sulit untuk menjangkau pelayanan kesehatan

\section{Saran}

Bagi profesi khususnya pengelola program KIA diharapkan dapat lebih memperhatikan masyarakat yang memiliki bayi maupun balita agar melakukan imunisasi sesuai interval dengan lebih memperbanyak posyandu yang ada di desa sehingga lebih dekat dengan masyarakat sehingga cakupan imunisasi di Puskesmas Punggelan 2 dapat lebih baik lagi.

\section{DAFTAR PUSTAKA}


[1] Marmi dan Kukuh Rahardjo. 2012. Asuhan Neonatus, Bayi, Balita dan Anak Pra Sekolah. Yogyakarta: Pustaka Pelajar.

[2] Ranuh, Hariyanto, dkk. 2011. Pedoman Imunisasi di Indonesia. Jakarta: Penerbit Ikatan Dokter Anak Indonesia.

[3] Muslihatun, wafi Nur. 2010. Asuhan Neonatus Bayi dan Balita. Yogyakarta: Fitramaya.

[4] Rukiyah, Ai Yeyeh dan Lia Yulianti. 2010. Asuhan Neonatus Bayi dan Anak Balita. Jakarta: Trans Info Media.

[5] Notoatmodjo, Soekidjo. 2005. Metodelogi Penelitian Kesehatan. Jakarta: Rineka Cipta.

[6] Hidayat, A. Aziz Alimul. 2011. Metode Penelitian Kebidanan \& Teknik Analisis Data. Jakarta: Salemba Medika.

[7] Pohan, Imbalo S. 2006. Jaminan Mutu Layanan Kesehata. Jakarta.

[8] Kurniati, Anna dan Ferry Efendi. 2012. Kajian SDM Kesehatan di Indonesia. Jakarta: Salemba Medika.

[9] Carpenito, Lynda Juall. 2009. Diagnosis Keperawatan Aplikasi pada Praktik Klinis. Jakarta: EGC.

[10] Asmadi. 2008. Konsep Dasar Keperawatan. Jakarta: EGC. 


\section{PEDOMAN PENULISAN NASKAH JKM}

Jurnal Kesehatan Masyarakat (JKM) STIKES Cendekia Utama Kudus menerima naskah hasil-hasil riset, artikel ilmiah, studi/ analisa kritis, skripsi, tesis, disertasi dan tulisan ilmiah lain di bidang kesehatan masyarakat.

Naskah adalah karya asli penulis/ peneliti, bukan plagiat, saduran atau terjemahan karya penulis/ peneliti lain. Naskah khusus ditujukan kepada Jurnal Kesehatan Masyarakat (JKM) STIKES Cendekia Utama Kudus, belum pernah dipublikasikan di media lain.

Naskah yang dikirim harus disertai surat persetujuan publikasi dan surat pengantar yang ditandatangani peneliti/ penulis.

Komponen naskah:

- Judul, ditulis maksimal 150 karakter, huruf Book Antiqua, ukuran 13, spasi 1

- Identitas penulis, ditulis setelah judul. Terdiri atas nama (tanpa gelar), alamat tempat kerja, nomor telepon/hp dan alamat email.

- Abstrak dalam bahasa Indonesia dan bahasa Inggris, maksimal 200 kata, disusun dalam satu alinea, berisi masalah, tujuan, metode, hasil dan 3-5 kata kunci. Untuk naskah dalam bahasa Inggris, tidak perlu disertai abstrak dalam bahasa Indonesia.

- Pendahuluan, tanpa subjudul, berisi latar belakang, sedikit tinjauan pustaka dan tujuan penelitian.

- Metode penelitian, dijelaskan secara rinci, disain, populasi, sampel, sumber data, teknik/ instrumen pengumpul data, dan prosedur analisis data.

- Hasil dan Pembahasan, mengurai secara tepat dan argumentatif hasil penelitian, kaitan hasil dengan teori yang sesuai dan sistematis.

- Tabel atau gambar. Tabel, diberi nomor sesuai urutan penyebutan dalam teks, ditulis 1 (satu) spasi, ukuran 11. Judul singkat, padat dan jelas, terletak di atas tabel. Gambar, diberi nomor sesuai urutan penyebutan dalam teks. Judul singkat, padat dan jelas, terletak di bawah gambar.

- Simpulan dan Saran. Simpulan menjawab masalah penelitian, pernyataan tegas. Saran logis, tepat guna dan tidak mengada-ada, dan ada keterkaitan dengan keberlanjutan penelitian

- Rujukan/ referensi ditulis sesuai aturan Vancouver, urut sesuai dengan pemunculan dalam keseluruhan teks, maksimal 25 rujukan dan 75 persen merupakan publikasi dalam 10 tahun terakhir. 
Naskah sebanyak 15-25 halaman kuarto, batas atas-bawah-tepi kiri-tepi kanan (cm) : 4-3-4-3, spasi 1,5, jenis huruf: arial, ukuran 12, format Microsoft word, dalam bentuk softfle dan 3 (tiga) eksemplar dalam bentuk print out.

Naskah dikirim ke alamat : Redaksi Jurnal Kesehatan Masyarakat (JKM) STIKES Cendekia Utama Kudus, Jl. Lingkar Raya Km.05 Jepang Mejobo Kudus 59381.

Kontak langsung dapat melalui:

- Eko Prasetyo : 081228475759 / 081575435102

- Sri Wahyuningsih : 085740572288

Naskah juga dapat dikirim melalui email : jkm.cendekiautama@gmail.com

\section{Contoh penulisan daftar pustaka :}

\section{Artikel Jurnal Penulis Individu}

Sloan NL, Winikoff B, Fikree FF. An ecologic analysis of maternal mortality ratios. Stud Fam Plann 2001;32:352-355.

\section{Artikel Jurnal Penulis Organisasi}

Diabetes Prevention Program Research Group. Hypertension, insulin, and proinsulin in participants with impaired glucose tolerance. Hypertension.2002;40(5):679-86

\section{Artikel Jurnal di Internet}

Goodyear-Smith F and Arroll B, Contraception before and after termination of pregnancy: can we do it better? New Zealand Medical Journal, 2003, Vol. 116, No. 1186, <http://www.nzma.org.nz/journal/1161186/683/content. pdf>, accessed Aug. 7, 2007.

\section{Buku Dengan Nama Editor sebagai penulisnya}

Lewis G, ed. Why mothers die 2000-2002: the confdential enquiries into maternal deaths in the United Kingdom. London: RCOG Press; 2004.

\section{Buku yang Ditulis Individu}

Loudon I. Death in childbirth. An international study of maternal care and maternal mortality 1800-1950.London: Oxford University Press, 1992.50

\section{Buku yang Ditulis Organisasi}

Council of Europe, Recent Demographic Developments in Europe 2004,Strasbourg, France: Council of Europe Publishing, 2005. 


\section{Artikel dari Buletin}

Ali MM, Cleland $\mathrm{J}$ and Shah $\mathrm{IH}$, Condom use within marriage: a neglected HIV intervention, Bulletin of the World Health Organization, 2004, 82(3):180-186.

\section{Paper yang Dipresentasikan dalam Pertemuan IImiah/Konferensi}

Kaufman J, Erli Z and Zhenming X, Quality of care in China: from pilot project to national program, paper presented at the IUSSP XXV International Population Conference, Tours, France, July 18-23, 2005.

\section{BAB dalam Buku}

Singh S, Henshaw SK and Berentsen K, Abortion: a worldwide overview, in: Basu AM, ed., The Sociocultural and Political Aspects of Abortion,Westport, CT, USA: Praeger Publishers, 2003, pp. 15-47.

\section{Data dari Internet}

U.S. Bureau of the Census, International Data Base, Country summary: China, 2007, <http://www.census.gov/ipc/www/idb/country/chportal.html>, accessed Aug. 12, 2007.

\section{Disertasi}

Lamsudin R. Algoritma Stroke Gadjah Mada (Disertasi). Yogyakarta: Universitas Gadjah Mada. 1997

\section{Makalah dalam Surat Kabar}

Banzai VK, Beto JA. Treatment of Lupus Nephritis. The Jakarta Post 1989; Dec 8; Sect A.5(col 3)

\section{Kamus}

Ectasia. Dorland's Illustrated Medical Dictionary.27th ed. Philadelphia: Saunders, $1988 ; 527$ 


\title{
UCAPAN TERIMA KASIH DAN PENGHARGAAN
}

\author{
Kepada Yang Terhormat : \\ Sigit Ari Saputro, S.KM., M.Kes. \\ Universitas Airlangga, Surabaya, Indonesia \\ dr. Mahalul Azam, M.Kes. \\ Universitas Negeri Semarang, Indonesia \\ Eti Rimawati, S.KM., M.Kes. \\ Universitas Dian Nuswantoro, Semarang, Indonesia \\ Didik Sumanto, S.KM., M.Kes. (Epid) \\ Universitas Muhammadiyah Semarang, Indonesia \\ Selaku reviewer (Mitra Bestari) dari \\ Jurnal Kesehatan Masyarakat (JKM) Cendekia Utama \\ STIKES Cendekia Utama Kudus
}

